\title{
A Field Study on Biochemical Changes Associated with Salmonella Infection in Ducklings
}

\author{
Mayada A.M. Abou Zeid ${ }^{1 *}$, Soad A. Nasef ${ }^{2}$, Gehan, I. E. Ali ${ }^{3}$ and Hegazy, A.M. ${ }^{4}$ \\ ${ }^{1}$ Bacteriology, Kafr El sheikh Regional Laboratory, Animal Health Research Institute, Agricultural Research Center (ARC), Egypt. \\ ${ }^{2}$ Reference Laboratory for Veterinary Quality Control on Poultry Production, Animal Health Research Institute, Agricultural Research Center (ARC), Egypt. \\ ${ }^{3}$ Biochemistry, Kafr El sheikh Regional Laboratory, Animal Health Research Institute, Agricultural Research Center (ARC), Egypt. \\ ${ }^{4}$ Poultry diseases, Kafr El sheikh Regional Laboratory, Animal Health Research Institute, Agricultural Research Center (ARC), Egypt. \\ "Corresponding author's Email: kindmemo@ yahoo.com; ORCID: 0000-0002-5733-8606
}

Received: 22 Feb. 2020

Accepted: 28 Mar. 2020

\begin{abstract}
The present study aimed to investigate the incidence of Salmonella infection in diarrheic ducklings in Kafr El Sheikh Governorate, Egypt. A total of 100 samples were collected from ducklings suffered from diarrhea and mortality. Also, 50 litter samples were collected from duck farms. All specimens were collected under aseptic conditions for the isolation of Salmonella spp. The incidence of Salmonella was 7\% in pooled samples from cecum, liver, spleen and gall bladder and 6\% in litter samples. Ten strains of Salmonella spp. were serotyped, of which, S. Salamae (1 strain), $S$. Miami (2 strains), $S$. Kentucky (4 strains), $S$. Paratyphi A (2 strain) and $S$. Magherafelt (1 strain) were detected. Susceptibility of Salmonella isolates to 10 antimicrobial agents showed that Salmonella isolates were highly sensitive to amikacin (100\%), followed by trimethoprim/sulphamethoxazole and gentamicin (50\%). While isolates showed the highest percentage of resistance to norfloxacin (90\%), followed by ciprocin (70\%), flumox (70\%) and amoxicillin-clavulanic acid (70\%). Virulence genes (invA, hilA, and fimA) were detected by PCR assay, all 10 Salmonella isolates showed positive results for three virulence genes, which gave specific amplicon at 284, 150, and 85 base pairs, respectively. Lethality test in five groups of three-day-old ducklings with different five isolated strains indicated a mortality rate ranged from $20-30 \%$ in three isolates only. The most lethal strain S. Paratyphi A was chosen for further investigation as a pathogenicity test. IL-6 slightly decreased in the infected group in comparison to control. The results indicated that ducks infected with Salmonella spp. significantly showed lower RBCs, Hb, PCV, Phagocytic activity, phagocytic index, and serum albumin while, significantly had higher WBCs, neutrophil, lymphocyte, serum globulin, uric acid, creatinine, AST and ALT concentrations compared to non-infected. It could be concluded that Salmonella has hepatic and renal destructive effects and immunosuppressive effects.
\end{abstract}

Keywords: Biochemical changes, Ducklings, Salmonella.

\section{INTRODUCTION}

Salmonella infections are a major problem in the poultry industry. These bacteria enter the human food chain through poultry products. Human Salmonella infections and food-poisoning take the form of gastroenteritis, which can result in death in highly susceptible individuals (Here et al., 2003). Salmonella is a significant source of foodborne maladies that cause morbidity and mortality around the world. Among 94 million cases of non-typhoid Salmonella contaminations, it was assumed that roughly $85 \%$ of the cases were initiated by nourishment root Salmonella (Chiu et al., 2010).

Salmonella contaminations are too vital as both a cause of clinical infection in duck and as a source of nourishment borne transmission of sickness to people. Overwhelming financial problems happen due to morbidity, mortality, decreased egg and meat creation in duck. Mortality may shift from $10 \%$ to $80 \%$ or higher in extreme episodes (Kleven and Yoder, 1998). Numerous Salmonella serovars exist. More than 2,600 serovars are grouped depending on the reactivity of antisera to $\mathrm{O}$ and $\mathrm{H}$ antigens (Stevens et al., 2009), and the serovars from ranches have a critical cover with those causing sicknesses in people (Alcaine et al., 2006). For the control and treatment of Salmonella, antimicrobials use is important. However, multidrug-resistant Salmonella has emerged and lead to treatment failure (Gong et al., 2013).

The Salmonella virulence is linked to a combination of chromosomal and plasmid factors. There are different genes such as inv, spv, fim $A$ and stn have been identified as major virulence genes responsible for salmonellosis. Salmonella pathogenicity islands are huge gene tapes inside the Salmonella chromosome that encode 
determinants liable for building up particular associations with the host. Also, it required for bacterial virulence (Sabbagh et al., 2010).

Salmonella spp. enter the intestinal epithelium and penetrates the Peyer's patches and from the Peyer's patches, Salmonella spp. go toward the mesenteric lymph nodes where it spreads to the circulatory system, leading to transient bacteremia (Smith and Beal, 2008). In this phase, there is massive chemotaxis of chemokines (IL-8, CXC, MIP-1 $\beta$ ) together with IL-1 and IL-6 into intestinal mucosa Bacteria are rapidly cleared from the blood by phagocytes in the spleen and liver, and a large fraction of bacteria are killed by these cells (Coble et al., 2011).

The current study was performed to isolate and identify Salmonella serovars isolated from ducks using serological techniques and also to study the antibiotic sensitivity of the isolates. PCR assay was used for detecting Salmonella virulence genes. Also, the pathogenicity of isolated strains and changes of biochemical parameters and immune response during Salmonella infection in ducks were investigated.

\section{MATERIAL AND METHODS}

\section{Ethical approval}

The study was conducted according to the institutional Animal Care and Use Committee (Vet. CU20022020149)

\section{Collection of samples}

A total of 100 samples from 100 ducklings which suffer from diarrhea and mortality were collected from different farms and transported to Animal Health Research Institute Kafr El sheikh branch for examination. Samples from live and fresh dead birds were taken for isolation and identification of Salmonella spp. as pooled samples from the cecum, liver, spleen and gall bladder were collected in sterile containers to be cultured bacteriologically. Also, 50 Litter samples were collected from duck farms from dry areas of floor litter from the upper $2.5-5 \mathrm{~cm}$ of litter in sterile plastic bags and transported to the lab for bacterial examination.

\section{Isolation of Salmonella spp.}

Samples were cultured in Rappaport Vassiliadis Broth at $37{ }^{\circ} \mathrm{C}$ for $18 \mathrm{hrs}$. and then subcultured on Salmonella and Shigella agar and incubated at $35^{\circ} \mathrm{c}$ for 24 hrs and XLD agar at $37{ }^{\circ} \mathrm{C}$ for $24-48$ hrs. Salmonella was isolated from poultry litter according to the American Association of Avian Pathologists (AAAP) (1989).
Isolates were identified as Salmonella spp. based on their colony morphology on selective media, biochemical testing (Edwards and Ewing, 1986). Isolates that were biochemically identified as Salmonella spp. were confirmed serologically by using the Polyvalent Salmonella (A-E and Vi) antisera (Benex Ltd., Shannon, Ireland). Serological identification of Salmonella was performed according to Grimont and Weill (2007).

\section{Antimicrobial susceptibility test of isolated Salmonella spp.}

Antimicrobial susceptibility was assessed using a disk diffusion method according to CLSI protocols (CLSI, 2018). Sensitivity discs with variable concentrations were used to determine the susceptibility of the isolated strains. The following antibiotics (Bioanalyse, Epico, and HiMedia) were used: norfloxacin, ciprocin, flumox, amoxicillin-clavulanic acid, ampicillin, trimethoprim/ sulphamethoxazole, doxycycline, gentamicin, cefotaxime, and amikacin. The multidrug-resistant isolates which resistant to three or more kinds of antimicrobials (Schwarz et al., 2010).

\section{Virulence genes of Salmonella detection by PCR}

\section{DNA extraction}

DNA extraction from examined samples was done by using the QIAamp DNA Mini kit (Qiagen, Germany, $\mathrm{GmbH}$ ) with alterations from the manufacturer's suggestions Briefly, $10 \mu \mathrm{l}$ of proteinase $\mathrm{K}$ and $200 \mu \mathrm{l}$ of lysis buffer was incubated with $200 \mu \mathrm{l}$ of the tested suspension at $56^{\circ} \mathrm{C}$ for $10 \mathrm{~min}$. After incubation, $100 \%$ ethanol was put to the lysate by $200 \mu 1$. The tested sample washed and then centrifuged following the manufacturer's order. $100 \mu \mathrm{l}$ of elution buffer was used to elute the nucleic acid which provided in the kit.

\section{PCR amplification}

The Primerswhich used were provided by Metabion (Germany) are listed in table 1. Primers were used in a 25 $\mu 1$ of reaction mixture containing $12.5 \mu 1$ of EmeraldAmp Max PCR Master Mix (Takara, Japan), $1 \mu 1$ of each primer of 20 pmol condensations, $4.5 \mu \mathrm{l}$ of water, and $6 \mu \mathrm{l}$ of DNA template. The reaction was performed in a T3 Biometra thermal cycler.

\section{Analysis of the PCR Products}

The PCR product was isolated by electrophoresis on $1.5 \%$ agarose gel (Applichem, Germany, $\mathrm{GmbH}$ ) in $1 \mathrm{x}$ TBE buffer at room temperature using gradients of $5 \mathrm{~V} / \mathrm{cm}$. To form gel analysis, about $20 \mu 1$ from products were loaded in each gel slot. A gel pilot 100 bp DNA Ladder 
(Qiagen, Germany, $\mathrm{GmbH}$ ) and gene ruler 50 bp ladders (Fermentas, Thermo) were used to detect the segment sizes. Gel documentation system (Alpha Innotech, Biometra) was used for photographing the gel and the computer software was used to analyze the data.

\section{Lethality test}

In this test, six groups of three-day-old duckling were used (ten ducks per group for the five isolates $(S$. Salamae, $S$. Miami, $S$. Kentucky, $S$. Paratyphi A, and $S$. Magherafelt) and last group as a negative control). A day before infection (challenge), randomly bacteriological samples were collected from ducks and tested for Salmonella free. Each duck was inoculated oral inoculation (using $1 \mathrm{ml}$ sterile feeding tube introduced into the crop) with $1 \mathrm{ml}$ of overnight Salmonella isolates suspension $\left(1 \times 10^{8} \mathrm{CFU} / \mathrm{ml}\right)$. The organism was prepared according to Osman et al. (2010). Morbidity and mortality rates following oral inoculation were observed until 15 days (Bjerrum et al., 2003). The most lethal strain was chosen for further investigation as pathogenicity test (its effect on performance of duck, shedding and organ colonization)

\section{Pathogenicity study}

One group of 3-day old duckling and another group as control (20 birds for each) were separately housed in controlled biosafety isolator. Birds were fed rations of antibiotic-free. A day before infection (challenge) samples were collected and tested for Salmonella free. Birds were fasted for 12 hours to decrease crop bulk, thus expediting the flushing of the crop. The organism was prepared according to Osman et al. (2010). Infection dose was 1 milliliter of dilution introduced orally for all infected ducks with $1 \times 10^{8} \mathrm{CFU} / \mathrm{ml}$ Salmonella concentration for studying morbidity and mortality rates following oral inoculation were observed to 45 days, The control group was inoculated oral inoculation with1 milliliter of sterile saline. Fecal swabs were collected for detection of fecal shedding from all groups during the first 3 days PI, then at weekly interval till 45 days. Moreover, at the end of each week till 45 days, two randomly selected ducks were sacrificed from each group for postmortem and bacteriological examination (organ colonization).

\section{Detection of interleukin 6 by real-time PCR}

A. RNA extraction: RNA performed from spleen tissue samples by using a QIAamp RNeasy Mini kit (Qiagen, Germany, GmbH) when $30 \mathrm{mg}$ of the tissue sample was added to $600 \mu \mathrm{l}$ RLT buffer containing $10 \mu \mathrm{l}$ $\beta$-mercaptoethanol per $1 \mathrm{ml}$. To form the homogenization of the samples, the tubes were put in the adaptor sets, where it fixed into the clamps of the Qiagen tissue Lyser. Disruption was done in 2 minutes by high-speed $(30 \mathrm{~Hz})$ shaking step. One size of $70 \%$ ethanol was put on the cleared lysate, and the steps were done concurring to the Decontamination of Add up to RNA from Animal Tissues system of the QIAamp RNeasy Mini kit (Qiagen, Germany, GmbH). N.B. On column DNase, assimilation was done to evacuate leftover DNA.

B. Oligonucleotide Primers: Primers which used were provided from Metabion (Germany) are listed in table 2.

C. Taqman RT-PCR: PCR extension was done in a volume of $25 \mu \mathrm{l}$ containing $3 \mu \mathrm{l}$ of RNA format, $12.5 \mu \mathrm{l}$ of 2x QuantiTect Probe RT-PCR Master Mix, 8.125 $\mu$ l PCR grade water, $0.5 \mu 1$ from each primer of $20 \mathrm{pmol}$ condensation and $0.125 \mu \mathrm{l}$ of each probe (30 pmol cons.) and $0.25 \mu 1$ of QuantiTect RT Mix. On the Stratagene MX3005P real-time PCR machine The reaction was performed.

D. Analysis of RT-PCR results: Amplification curves and cycle threshold (CT) values were detected by the Stratagene MX3005P software. The gene expression difference on the RNA of the different samples was assessed, the CT of the tested sample was compared with the positive control group, according to the " $\Delta \Delta \mathrm{CT}$ " method mentioned by Yuan et al. (2006).

\section{Serum biochemical parameters}

Biochemical examinations of the one $\mathrm{ml}$ of blood samples were withdrawn from 3 selected ducks of each treatment via brachial vein puncture into EDTA tubes for hematological analysis and were placed inside an icebox and transferred to the laboratory. Hemoglobin ( $\mathrm{Hb})$ according to the cyanomethemoglobin technique (Jain, 1986), red blood cell and white blood cell counts using a Neubauer hemocytometer (Natt and Herrick, 1952) and packed cell volume (PCV) (Britton 1963) were measured. Differential leukocyte count was performed using blood smears stained according to the Rosenfeld method (Lucas andJamroz, 1961). Determination of phagocytic activity and phagocytic index (Richardson and Smith, 1982). Also, the blood samples were kept for $30 \mathrm{~min}$ at room temperature and the serum was collected through centrifugation at $3000 \mathrm{RPM}$ for $15 \mathrm{~min}$ and was used for Activities of Alanine Amino Transferase (ALT) and Aspartate Amino Transferase (AST) were determined according to Reitman and Frankel (1957). Uric acid and creatinine were determined according to Arliss and Entvistle, (1981), and Michael and Malcolm (2006) respectively. Also, the serum 
used to determine the total protein (TP) according to (Doumas et al., 1981), albumin (Alb) according to Henry et al., (1974), Globulins concentration (Glob) in serum was computed by subtracting albumin concentration from total Proteins, albumin to globulin ratio (A/G) was calculated according to Kaneko (1989).

\section{Statistical analysis}

Statistical analysis was performed using one-way analysis of variance using SAS software.

\section{RESULTS}

The result of serotyping of Salmonella isolates revealed five different Salmonella serotypes ( $S$. Salamae, $S$. Miami, $S$. Kentucky, $S$. Paratyphi A, and $S$. Magherafelt) with 1, 2, 4, 2 and 1 strains, respectively.

\section{Pathogenicity study}

Clinical signs, Postmortem findings and mortality rate

Clinical signs were observed in the group infected with $S$. Paratyphi A 48 hours post-inoculation (PI) in the form of extreme thirst, profuse diarrhea, huddling together as chilled, ruffled feathers in some of them, lameness. Staggering gait, tremors, retraction of the neck backward, paddling movement, coma, and death. PM lesions revealed severe congestion of all internal organs, enlargement of the spleen, enlargement, and lobulation of the kidney, distention of the ureters with urates. Also, the liver appeared very pale. The mortality rate was $30 \%$.
Quantification of interleukin-6 mRNA expression

A linear relationship between the amount of input RNA and the CT values for the various reactions was seen as expected in a $\log 10$ dilution series of standard samples for Interleukin 6 that also acted as positive controls for RT and PCR. Regression analysis of the CT values generated with the $\log 10$ dilution series of standards gave R2 values for all reactions that were greater than 0.97 . To account for the variation in sampling and RNA preparations, the CT values for cytokines and chemokines specific for each sample were standardized using the CT value for $28 \mathrm{~S}$ rRNA for the same sample from a reaction completed at the same time. Using the slopes of the Interleukin 6 and $28 \mathrm{~S}$ rRNA $\log 10$ dilution series regression lines, the difference in input total RNA, as represented by the $28 \mathrm{~S}$ rRNA, was then used to adjust cytokine- and chemokinespecific CT values (Table 8 ).

\section{Blood Parameters}

Infection with Salmonella spp. in ducks significantly $(\mathrm{P}<0.05)$ decreased RBCs, Hb, PCV, Phagocytic activity $\%$ and Phagocytic index while, significantly $(\mathrm{P}<0.05)$ increased WBCs, neutrophil, and lymphocyte compared with non-infected (Table 10).

\section{Kidney and liver functions related to serum parameters \\ Infection with Salmonella spp. in ducks significantly $(\mathrm{p}<0.05)$ decreased serum albumin while, significantly $(\mathrm{p}<0.05)$ increased blood serum globulin, uric acid, creatinine, AST and ALT concentrations compared with non-infected (Table 12).}

Table 1. Primer sequences, target genes, amplicon sizes, and cycling conditions.

\begin{tabular}{|c|c|c|c|c|c|c|c|c|}
\hline \multirow{2}{*}{$\begin{array}{l}\text { Target } \\
\text { gene }\end{array}$} & \multirow{2}{*}{ Primer sequences (5'-3') } & \multirow{2}{*}{$\begin{array}{l}\text { Amplified } \\
\text { segment } \\
\text { (bp) }\end{array}$} & \multirow{2}{*}{$\begin{array}{c}\text { Primary } \\
\text { denaturation }\end{array}$} & \multicolumn{3}{|c|}{ Amplification ( 35 cycles) } & \multirow{2}{*}{$\begin{array}{c}\text { Final } \\
\text { extension }\end{array}$} & \multirow{2}{*}{ Reference } \\
\hline & & & & $\begin{array}{c}\text { Secondary } \\
\text { denaturation }\end{array}$ & Annealing & Extension & & \\
\hline \multirow{2}{*}{ invA } & F:GTGAAATTATCGCCACGTTCGGGCAA & \multirow{2}{*}{284} & \multirow{2}{*}{$\begin{array}{c}94^{\circ} \mathrm{C} \\
5 \mathrm{~min}\end{array}$} & \multirow{2}{*}{$\begin{array}{c}94^{\circ} \mathrm{C} \\
30 \mathrm{sec} .\end{array}$} & \multirow{2}{*}{$\begin{array}{c}55^{\circ} \mathrm{C} \\
30 \mathrm{sec} .\end{array}$} & \multirow{2}{*}{$\begin{array}{l}72^{\circ} \mathrm{C} \\
30 \mathrm{sec} .\end{array}$} & \multirow{2}{*}{$\begin{array}{c}72^{\circ} \mathrm{C} \\
10 \mathrm{~min}\end{array}$} & \multirow{2}{*}{$\begin{array}{l}\text { Oliveira et } \\
\text { al. (2003) }\end{array}$} \\
\hline & R:TCATCGCACCGTCAAAGGAACC & & & & & & & \\
\hline \multirow[b]{2}{*}{ hilA } & F:CATGGCTGGTCAGTTGGAG & \multirow[b]{2}{*}{150} & \multirow{2}{*}{$\begin{array}{c}94^{\circ} \mathrm{C} \\
5 \mathrm{~min} .\end{array}$} & \multirow{2}{*}{$\begin{array}{c}94^{\circ} \mathrm{C} \\
30 \mathrm{sec} .\end{array}$} & \multirow{2}{*}{$\begin{array}{c}60^{\circ} \mathrm{C} \\
30 \mathrm{sec} .\end{array}$} & \multirow{2}{*}{$\begin{array}{l}72^{\circ} \mathrm{C} \\
30 \mathrm{sec}\end{array}$} & \multirow{2}{*}{$\begin{array}{l}72^{\circ} \mathrm{C} \\
7 \mathrm{~min}\end{array}$} & \multirow{2}{*}{$\begin{array}{l}\text { Yang et } \\
\text { al. (2014) }\end{array}$} \\
\hline & R:CGTAATTCATCGCCTAAACG & & & & & & & \\
\hline \multirow{2}{*}{$\operatorname{fim} A$} & F:CCT TTC TCC ATC GTC CTG AA & \multirow{2}{*}{85} & \multirow{2}{*}{$\begin{array}{c}94^{\circ} \mathrm{C} \\
5 \mathrm{~min} .\end{array}$} & \multirow{2}{*}{$\begin{array}{c}94^{\circ} \mathrm{C} \\
30 \mathrm{sec} .\end{array}$} & \multirow{2}{*}{$\begin{array}{c}50^{\circ} \mathrm{C} \\
30 \mathrm{sec} .\end{array}$} & \multirow{2}{*}{$\begin{array}{c}72^{\circ} \mathrm{C} \\
30 \mathrm{sec}\end{array}$} & \multirow{2}{*}{$\begin{array}{l}72^{\circ} \mathrm{C} \\
7 \mathrm{~min}\end{array}$} & \multirow{2}{*}{$\begin{array}{l}\text { Cohen et } \\
\text { al. (1996) }\end{array}$} \\
\hline & R:TGG TGT TAT CTG CCT GAC CA & & & & & & & \\
\hline
\end{tabular}

R: reverse, F: forward 
Table 2. Primer sequences, target genes and cycling conditions for TaqMan RT-PCR.

\begin{tabular}{|c|c|c|c|c|c|c|}
\hline \multirow{2}{*}{$\begin{array}{l}\text { Target } \\
\text { gene }\end{array}$} & \multirow{2}{*}{$\begin{array}{l}\text { Primers and probes sequences } \\
\left(5^{\prime}-3^{\prime}\right)\end{array}$} & \multirow{2}{*}{$\begin{array}{c}\text { Reverse } \\
\text { transcription }\end{array}$} & \multirow{2}{*}{$\begin{array}{l}\text { Primary } \\
\text { denaturation }\end{array}$} & \multicolumn{2}{|c|}{ Amplification (40 cycles) } & \multirow{2}{*}{ Reference } \\
\hline & & & & $\begin{array}{c}\text { Secondary } \\
\text { denaturation }\end{array}$ & $\begin{array}{c}\text { Annealing } \\
\text { and extension }\end{array}$ & \\
\hline \multirow{2}{*}{$\begin{array}{l}28 S \\
r R N A\end{array}$} & F:GGCGAAGCCAGAGGAAACT & \multirow{3}{*}{$\begin{array}{c}50^{\circ} \mathrm{C} \\
30 \mathrm{~min}\end{array}$} & \multirow{3}{*}{$\begin{array}{c}94^{\circ} \mathrm{C} \\
15 \mathrm{~min}\end{array}$} & \multirow{3}{*}{$\begin{array}{l}94^{\circ} \mathrm{C} \\
15 \mathrm{sec}\end{array}$} & \multirow{3}{*}{$\begin{array}{l}60^{\circ} \mathrm{C} \\
1 \mathrm{~min}\end{array}$} & \multirow{3}{*}{$\begin{array}{l}\text { Suzuki } \\
\text { et al. } \\
\text { (2009) }\end{array}$} \\
\hline & $\begin{array}{l}\text { TaqMan probe: } \\
\text { (FAM)AGGACCGCTACGGACCTCCACCA (TAMRA) }\end{array}$ & & & & & \\
\hline$I L-6$ & F:GCTCGCCGGCTTCGA & & & & & \\
\hline
\end{tabular}

Table 3. Incidence of Salmonella spp. isolated from ducklings and duck farms, Egypt

\begin{tabular}{lccc}
\hline Types of samples & $\begin{array}{c}\text { No. of } \\
\text { samples }\end{array}$ & $\begin{array}{c}\text { No. of } \\
\text { positive } \\
\text { samples }\end{array}$ & $\begin{array}{c}\text { Percentage } \\
\%\end{array}$ \\
\hline $\begin{array}{l}\text { Pooled samples from cecum, } \\
\text { liver, spleen and gall bladder }\end{array}$ & 100 & 7 & 7 \\
Litter samples & 50 & 3 & 6 \\
\hline
\end{tabular}

Table 4. The results of antimicrobial susceptibility test of Salmonella spp. $(\mathrm{n}=10)$ isolated from ducklings, Egypt

\begin{tabular}{|c|c|c|c|c|c|c|}
\hline \multirow{2}{*}{$\begin{array}{l}\text { Antimicrobial } \\
\text { agent }\end{array}$} & \multicolumn{2}{|c|}{ Susceptible } & \multicolumn{2}{|c|}{ Intermediate } & \multicolumn{2}{|c|}{ Resistant } \\
\hline & No. & $\%$ & No. & $\%$ & No. & $\%$ \\
\hline Norfloxacin & 1 & 10 & - & - & 9 & 90 \\
\hline Ciprocin & - & - & 3 & 30 & 7 & 70 \\
\hline Flumox & - & - & 3 & 30 & 7 & 70 \\
\hline $\begin{array}{l}\text { Amoxicillin- } \\
\text { Clavulanic acid }\end{array}$ & 3 & 30 & - & - & 7 & 70 \\
\hline Ampicillin & 3 & 30 & - & - & 7 & 70 \\
\hline $\begin{array}{l}\text { Trimethoprim / } \\
\text { Sulphamethoxazole }\end{array}$ & 5 & 50 & - & - & 5 & 50 \\
\hline Doxycycline & 3 & 30 & 2 & 20 & 5 & 50 \\
\hline Gentamicin & 5 & 50 & 4 & 40 & 1 & 10 \\
\hline Cefotaxime & 2 & 20 & 8 & 80 & - & - \\
\hline Amikacin & 10 & 100 & - & - & - & - \\
\hline
\end{tabular}

Table 5. Detection of invA, hilA, fimA virulence genes by PCR in Salmonella serotypes isolated from ducklings and litter duck farms, Egypt.

\begin{tabular}{|c|c|c|c|}
\hline Serotype $\quad$ Gene & $i n v A$ & hilA & $\operatorname{fim} A$ \\
\hline S. Salamae & $1+$ ve strain & $1+$ ve strain & $1+$ ve strain \\
\hline S. Miami & $2+$ ve strain & $2+$ ve strain & $2+$ ve strain \\
\hline S. Kentucky & 4+ve strains & 4+ve strains & 4+ve strains \\
\hline$S$. Paratyphi A & $2+$ ve strain & $2+$ ve strain & $2+$ ve strain \\
\hline S. Magherafelt & $1+$ ve strain & 1+ve strain & $1+$ ve strain \\
\hline
\end{tabular}

Table 6. Mortality rates in ducks infected with different Salmonella isolates through oral inoculation.

\begin{tabular}{lccc}
\hline Strain & $\begin{array}{c}\text { No. of } \\
\text { infected duck }\end{array}$ & $\begin{array}{c}\text { No. of } \\
\text { deaths }\end{array}$ & $\begin{array}{c}\text { Percentage } \\
\text { \% }\end{array}$ \\
\hline S. Salamae & 10 & 0 & 0 \\
S. Miami & 10 & 2 & 20 \\
S. Kentucky & 10 & 0 & 0 \\
S. Paratyphi A & 10 & 3 & 30 \\
S. Magherafelt & 10 & 2 & 20 \\
\hline
\end{tabular}

Table 7. Fecal shedding and mortality of experimentallyinfected ducks with Salmonella Paratyphi A

\begin{tabular}{lcc}
\hline Time & $\begin{array}{c}\text { Mortality } \\
\text { (number) }\end{array}$ & $\begin{array}{c}\text { Number of positive } \\
\text { ducks for Salmonella } \\
\text { shedding (\%) }\end{array}$ \\
\hline 1st day & - & $12(60)$ \\
2nd day & 2 & $13(72.2)$ \\
3rd day & 1 & $15(88.2)$ \\
End of $1^{\text {st }}$ week & 1 & $14(100)$ \\
End of $2^{\text {nd }}$ week & 2 & $7(70)$ \\
End of $3^{\text {rd }}$ week & - & $3(37.5)$ \\
End of 4th week & - & $3(50)$ \\
End of 5th week & - & $1(25)$ \\
After 45 days & - & 0 \\
\hline
\end{tabular}

Table 8. Reisolation of Salmonella from internal organs of experimentally infected ducks with Salmonella Paratyphi A $(n=18)$

\begin{tabular}{lcc}
\hline \multirow{2}{*}{ Organ } & \multicolumn{2}{c}{ S. Paratyphi A } \\
\cline { 2 - 3 } & No & \% \\
\hline Liver & 10 & 55.5 \\
Spleen & 12 & 66.6 \\
Gall bladder & 7 & 38.8 \\
Cecum & 11 & 61.1 \\
\hline
\end{tabular}


Table 9. Detection of interleukin-6 mRNA and 28S rRNA in spleen of control and Salmonella infected ducklings by realtime PCR

\begin{tabular}{|c|c|c|c|c|c|c|c|}
\hline \multirow{3}{*}{ Groups } & \multirow{3}{*}{ Sample No. } & \multicolumn{2}{|c|}{ 28S rRNA } & \multicolumn{4}{|c|}{ Interleukin-6 } \\
\hline & & \multirow{2}{*}{$\begin{array}{c}\text { Individual } \\
\text { CT }\end{array}$} & \multirow{2}{*}{$\begin{array}{c}\text { Mean } \\
\text { CT }\end{array}$} & \multirow{2}{*}{$\begin{array}{c}\text { Individual } \\
\text { CT }\end{array}$} & \multirow{2}{*}{$\begin{array}{c}\text { Mean } \\
\text { CT }\end{array}$} & \multicolumn{2}{|c|}{ Fold change } \\
\hline & & & & & & Individual & Collective \\
\hline \multirow{2}{*}{ Control } & 1 & 20.53 & \multirow{2}{*}{20.42} & 23.68 & \multirow{2}{*}{23.59} & - & \multirow{2}{*}{$\begin{array}{l} \\
-\end{array}$} \\
\hline & 2 & 20.30 & & 23.49 & & - & \\
\hline \multirow[b]{2}{*}{ Infected } & 1 & 20.38 & & 20.50 & \multirow{2}{*}{20.81} & 8.2821 & \multirow[b]{2}{*}{7.7633} \\
\hline & 2 & 20.64 & 20.60 & 20.89 & & 7.5685 & \\
\hline
\end{tabular}

CT: cycle threshold

Table 10. Effect of Salmonella challenge on some blood parameters of ducklings

\begin{tabular}{lcc}
\hline Items & $\begin{array}{c}\text { Non-infected } \\
\text { ducks }\end{array}$ & Infected ducks \\
\hline RBCs x $106 / \mathrm{mm} 3$ & $2.12 \pm 0.06^{\mathrm{a}}$ & $1.12 \pm 0.12^{\mathrm{b}}$ \\
$\mathrm{WBCs} \times 103 / \mathrm{mm} 3$ & $26.5 \pm 0.87^{\mathrm{b}}$ & $51 \pm 0.32^{\mathrm{a}}$ \\
$\mathrm{Hb}(\mathrm{g} / \mathrm{dl})$ & $8.08 \pm 0.12^{\mathrm{a}}$ & $5.6 \pm 0.32^{\mathrm{b}}$ \\
$\mathrm{PCV} \%$ & $34.98 \pm 0.33^{\mathrm{a}}$ & $18.48 \pm 1.76^{\mathrm{b}}$ \\
Lymphocyte\% & $29.93 \pm 1.81^{\mathrm{b}}$ & $36.38 \pm 1.11^{\mathrm{a}}$ \\
Neutrophil\% & $54.3 \pm 1.61^{\mathrm{b}}$ & $63.4 \pm 1.75^{\mathrm{a}}$ \\
Monocyte\% & $6.12 \pm 0.20^{\mathrm{a}}$ & $5.40 \pm 0.22^{\mathrm{a}}$ \\
Esinophil\% & $2.8 \pm 0.09^{\mathrm{a}}$ & $2.01 \pm 0.05^{\mathrm{a}}$ \\
Basophil\% & $5.6 \pm 0.53^{\mathrm{a}}$ & $4.08 \pm 0.23^{\mathrm{a}}$ \\
Phagocytic activity\% & $35.23 \pm 1.61^{\mathrm{a}}$ & $25.93 \pm 1.22^{\mathrm{b}}$ \\
Phagocytic index & $1.96 \pm 0.12^{\mathrm{a}}$ & $1.180 .32^{\mathrm{b}}$ \\
\hline Values are expressed as mean \pm standard error. Different superscript \\
letters within the same row indicate a significant difference $(\mathrm{p} \leq 0.05)$.
\end{tabular}

Table 11. Effect of Salmonella challenge on some serum biochemical parameters of ducklings

\begin{tabular}{lcc}
\hline Items & Non-infected ducks & Infected ducks \\
\hline Total protein $(\mathrm{g} / \mathrm{dl})$ & $5.94 \pm 0.08^{\mathrm{a}}$ & $5.86 \pm 0.05^{\mathrm{a}}$ \\
Albumin $(\mathrm{g} / \mathrm{dl})$ & $4.8 \pm 0.03^{\mathrm{a}}$ & $2.69 \pm 0.09^{\mathrm{b}}$ \\
Globulin $(\mathrm{g} / \mathrm{dl})$ & $0.80 \pm 0.08^{\mathrm{b}}$ & $1.1366 \pm 0.11^{\mathrm{a}}$ \\
Uric acid (mg/dl) & $7.74 \pm 0.05^{\mathrm{b}}$ & $11.04 \pm 0.02^{\mathrm{a}}$ \\
Creatinine (mg/dl) & $0.67 \pm 0.08^{\mathrm{b}}$ & $1.46 \pm 0.03^{\mathrm{a}}$ \\
AST $(\mathrm{u} / \mathrm{ml})$ & $42 \pm 0.46^{\mathrm{b}}$ & $67.3 \pm 0.38^{\mathrm{a}}$ \\
ALT (u/ml) & $49 \pm 0.27^{\mathrm{b}}$ & $82.3 \pm 1.2^{\mathrm{a}}$ \\
\hline
\end{tabular}

Values are expressed as mean \pm standard error. Different superscript letters within the same row indicate a significant difference $(\mathrm{p} \leq 0.05)$.

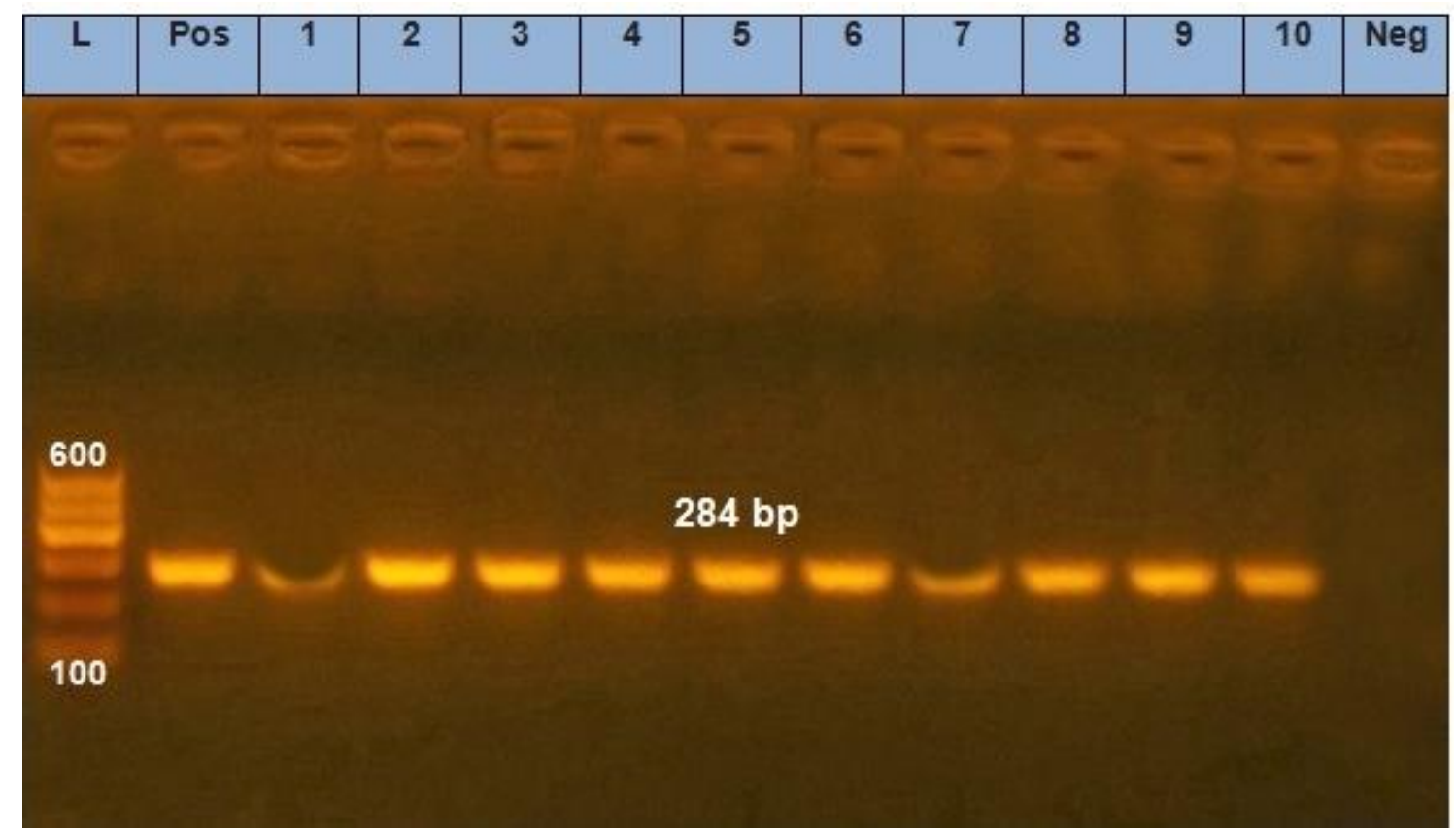

Figure 1. Detection of invA virulence gene in Salmonella isolates. Agarose gel showing polymerase chain reaction amplification of products of invA virulence gene of Salmonella. Lane L: 100-600 bp molecular size marker. Lane Pos: Control positive Salmonella invA virulence gene at 284 bp. Lane 1,2,3,4,5,6,7,8,9 and 10: samples positive for invA gene. 


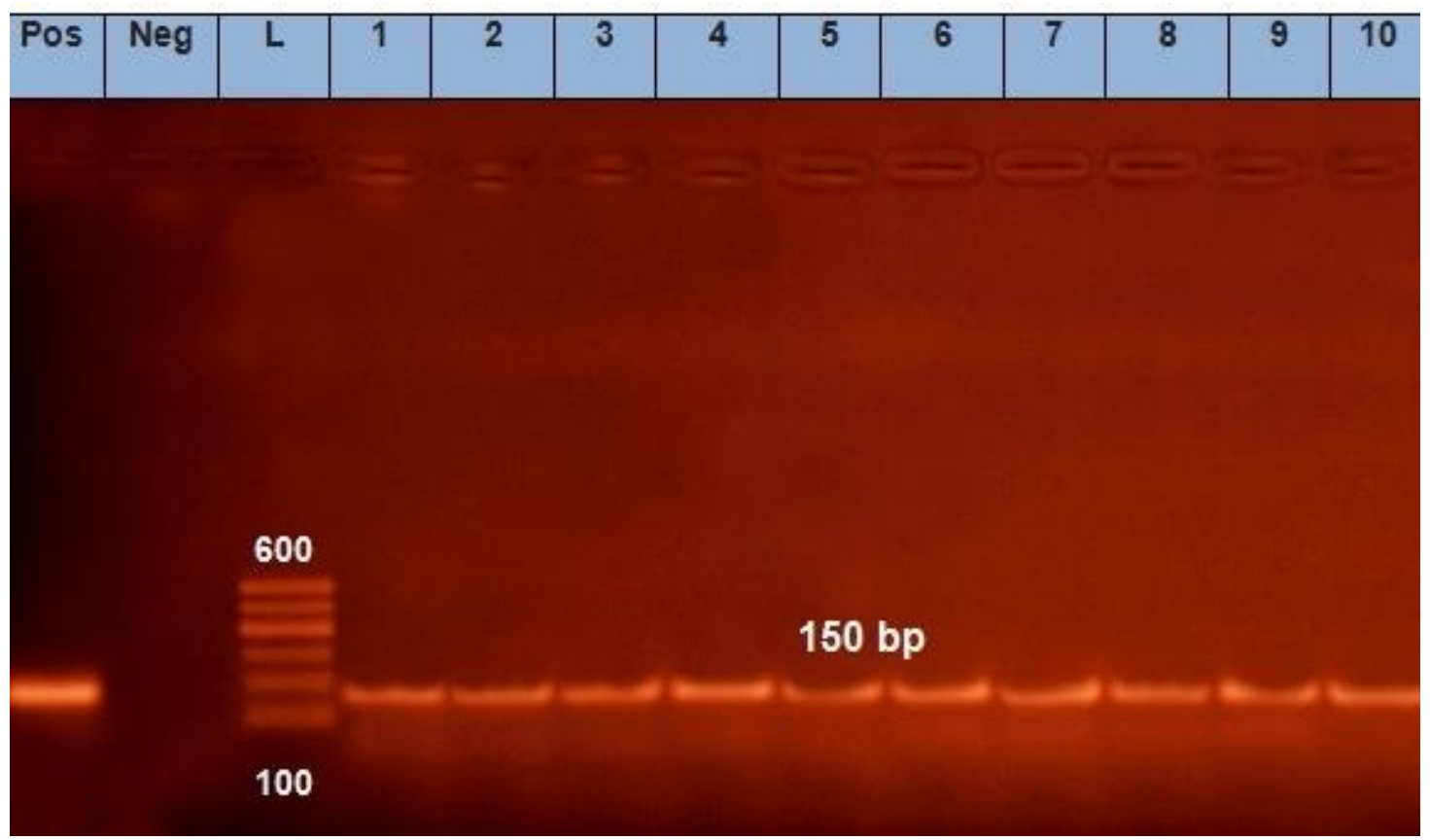

Figure 2. Detection of hilA virulence gene in Salmonella isolates. Agarose gel showing polymerase chain reaction amplification products of hilA virulence gene of Salmonella Lane L: 100-600 bp molecular size marker. Lane Pos: Control positive Salmonella hilA virulence gene at $150 \mathrm{bp}$. Lane 1, 2, 3,4,5,6,7,8,9 and 10: samples positive for hilA gene.

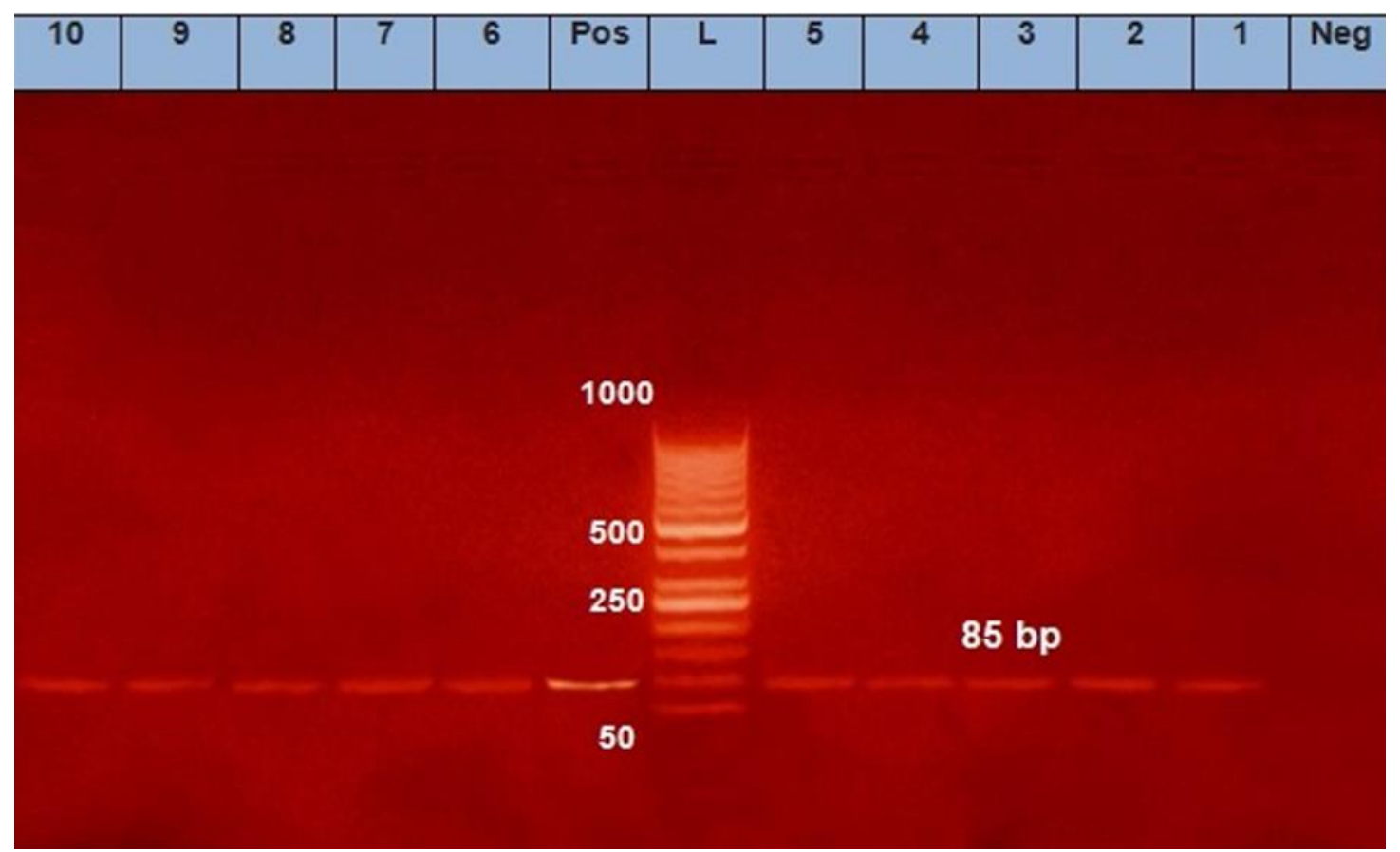

Figure 3. Detection of fimA virulence gene in Salmonella isolates. Agarose gel showing polymerase chain reaction amplification products of fimA virulence gene of Salmonella. Lane L: 50-1000 bp molecular size marker. Lane Pos: Control positive Salmonella fimA virulence gene at $85 \mathrm{bp}$. Lane 1, 2, 3,4,5,6,7,8,9 and 10: samples positive for fimA gene. 


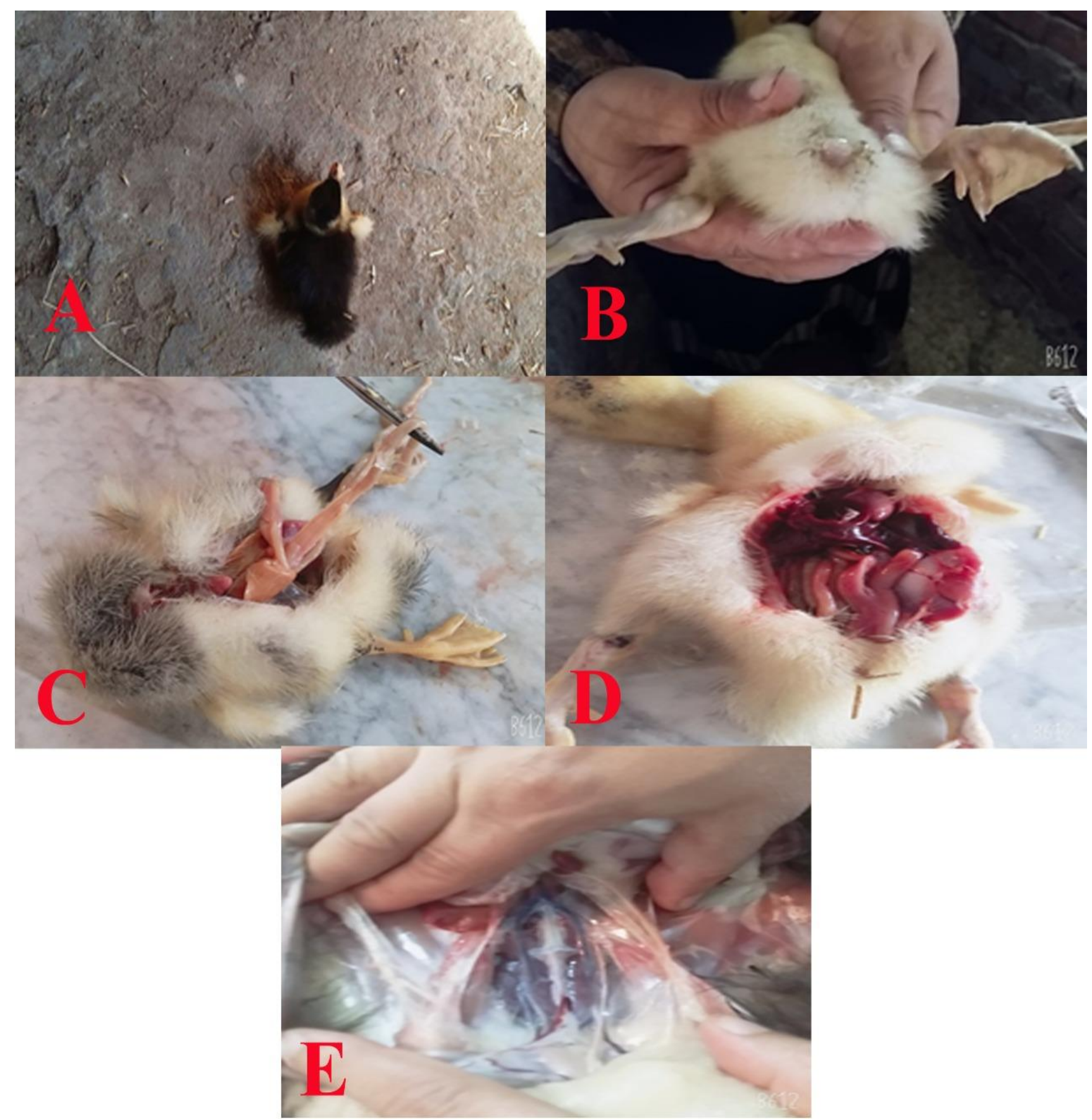

Figure 4. Clinical signs and postmortem lesions in experimentally Salmonella infected ducks. (A): staggering gait. (B): whitish diarrhea. (C): yellowish liver. (D): congested liver and intestine $1^{\text {st }}$ week post-infection. (E): congested kidney after 45 days post-infection. 


\section{Amplification Plots}

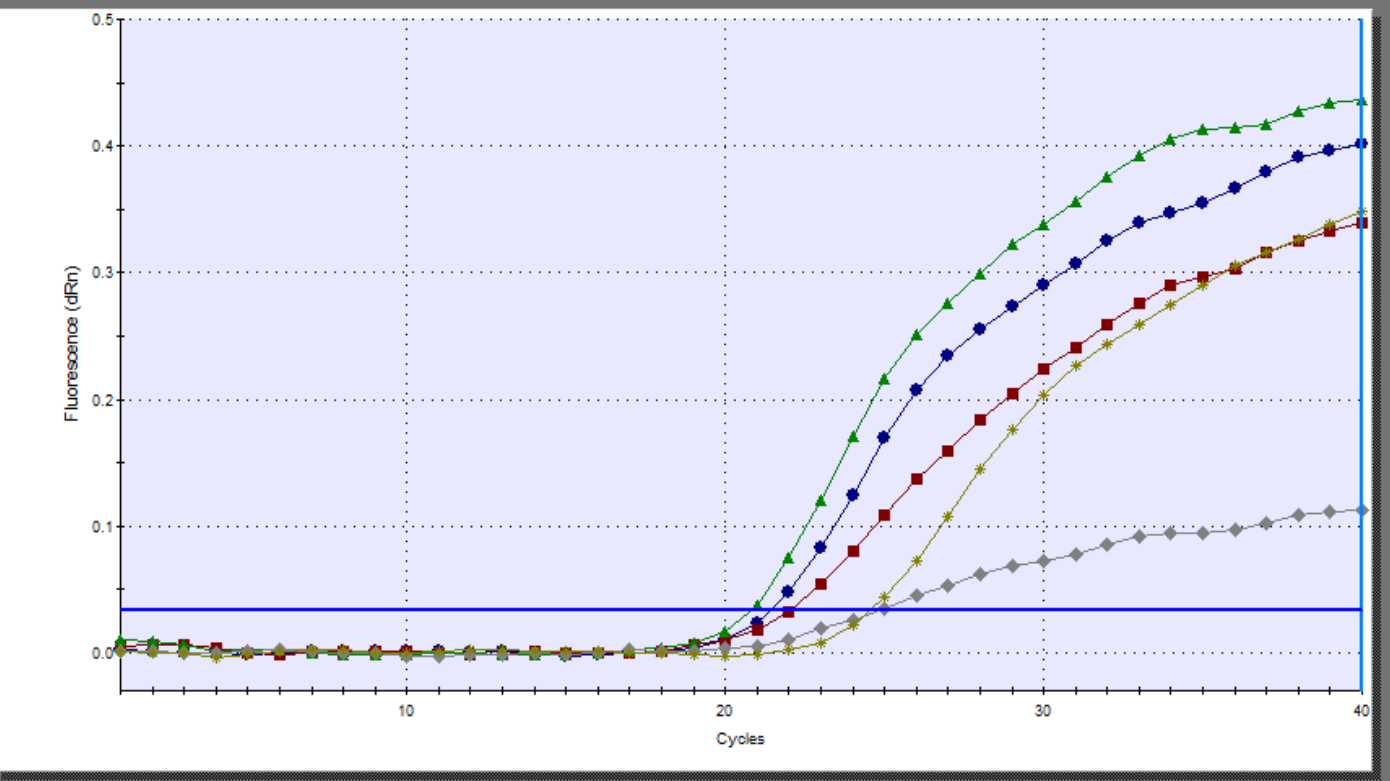

\section{Amplification Plots}

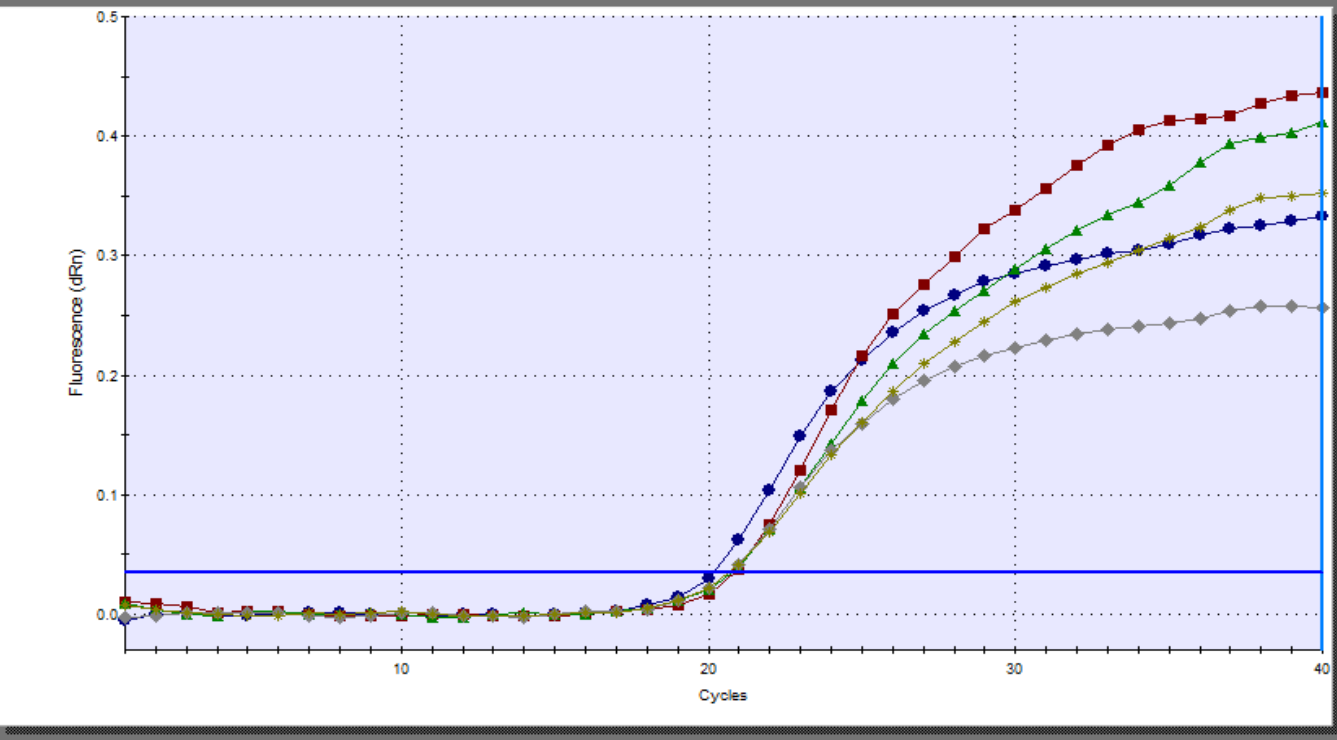

Figure 5. Expression of IL-6 and $28 \mathrm{~S}$ rRNA in spleen of ducks following infection with Salmonella. The data are fold changes in mRNA determined by quantitative RT-PCR.

\section{DISCUSSION}

In the present work, Salmonella was isolated from ducklings and litter with a rate of $7 \%$ and $6 \%$, respectively (Table 3), this rate appears to be similar to Abd El- Tawab et al. (2015) who isolated Salmonella from ducks in
Dakahlia and Damietta Governorates by $9.6 \%$ Batikh (2018), who isolated Salmonella from broiler chicken farm litter by $8 \%$, but these results differ from Shamoon et al., (1998) who isolated Salmonella from ducks in open houses which was 16.6\%, Abd-El-Rahman et al. (2000), who reported that the percentage of isolation was $20 \%$ 
from 10 duck flocks in North Sinai. Hoszowski and Wasyl (2005), who detected Salmonella in duck broilers with a percentage of $14.3 \%$, Adzitey and Huda (2012), who detected Salmonella in duck floor swab and transport crate swab with percentage of $13.3 \%$ for each.

The result of serotyping of 10 Salmonella isolates using "O", 'H" and "Vi" antisera are illustrated, which clarified that the serotype of Salmonella spp obtained from positive Salmonella samples were $S$. Salamae (1 Strain), $S$. Miami (2 strain), S. Kentucky (4 Strain), $S$. Paratyphi A (2 Strain), and $S$. Magherafelt (1 strain). The most prevalent serovar was $S$. Kentuky (4 strains), these results agreed with Elgohary et al. (2017), who reported that $S$. Kentuky is the most prevalent serovar in diarrheic young duckling and slaughtered ducks ( 2 serovars) for each, but these results disagree with Guran et al. (2017), who found that $S$. Kentucky has been rarely reported in ducks, however, it has been reported in other animals, such as chicken

According to the results concerning antimicrobial susceptibility tests presented in table 4,10 isolates showed the highest percentage of resistance (90\%) to norfloxacin, followed by ciprocin, flumox, and amoxicillin-clavulanic acid by $70 \%$ for each. these results were higher than those reported by Abd El-Tawab et al. (2015), who detected that the resistance to amoxicillin and ampicillin /sulbactam was $50 \%$ and $60 \%$ respectively in ducks isolates, but results of the present study were lower than Mohamed et al., (2015), who detected that the amoxicillin was $80 \%$ sensitive to Salmonella isolated from broilers, while in this study Salmonella isolates were amikacin sensitive by $100 \%$, followed by trimethoprim/sulphamethoxazole, gentamicin by $50 \%$ for each. Similar result was reported by Abd El-Tawab et al. (2015), who reported that Salmonella was sensitivity to amikacin by $100 \%$ and sulfa+trimethoprim by $60 \%$ in ducks isolates. All isolates were screened by PCR analysis for the presence or absence of three selected virulence genes (invA, hilA and fimA) (Table 5; Figures 1, 2 and 3). The most common virulence gene which presents in Salmonella, invA gene, was used as a PCR target gene for the detection of Salmonella (Dong et al., 2014). Also, PCR screening analysis detected the presence of invA, hilA, and fimA in all Salmonella isolates. These result agreement with Abd El-Tawab et al. (2017), who detected that the percentage of Salmonella Typhimurium virulence genes invA and hilA were $100 \%$ for each which isolated from clinically mastitic milk samples of cattle cows, Malorny et al. (2003), who revealed that in the studied strain that invA gene was detected in the rate of $100 \%$ and Thung et al. (2018), who detected Salmonella invA and hilA virulence genes were detected by $100 \%$ and $82.61 \%$ respectively in retail beef meat samples.Transmission of infection is generally considered to occur orally. Enormous bacterial increase happens inside the intestine and tissue attack happens quickly. Under test conditions, mortality created by a harmful strain may change from $25 \%$ to $100 \%$ between distinctive inbred lines (Barrow et al., 1987).

This study examined the lethality of Salmonella strains using 3-day-old ducklings (Table 6). The observations were done during 15 days and showed a low rate of morbidity rate (weakness, lethargy, and low growth rate) while, the mortality rate reached $30 \%$. Similar result was reported by Batikh (2018), who detected that the mortality was $28.6 \%$ in ducklings after inoculated orally with $S$.Bargny, $S$.Enteritidis and $S$. Kentucky strains.

The results indicated the pathogenesis of experimentally infected duckling with Salmonella Paratyphi A (Tables 7 and 8; Figure 4). Pathogenesis studies associated with virulent strains suggested that organisms multiply in the liver and spleen after the invasion and then disseminate to other organs, producing a systemic infection (Barrow et al., 1987). Ducks are very resistant to infection produced by Salmonella, they are possibly reservoirs of it and may shed it in the feces and pollutethe environment (Barrow et al., 1999). The present study revealed that colonization of the cecum and shedding of $S$. Paratyphi A in the feces was detected in the feces since $24 \mathrm{~h}$ post-infection, a similar result was reported by Ribeiro et al. (2005), who detected $S$. Kottbus in the feces of broiler chicks since $24 \mathrm{~h}$ until 42 days postinfection.

\section{Effect of Salmonella infection on interleukin 6}

In the bacteremia phase, there is massive chemotaxis of chemokines (IL-8, CXC, MIP-1 $\beta$ ) together with IL-1 and IL-6 into the intestinal mucosa. Bacteria are rapidly cleared from the blood by phagocytes in spleen and liver, and a large fraction of bacteria are killed by these cells (Coble et al., 2011). IL-6 decreased in the infected group in compared to control one (Table 9, Figure 5), these differed from (Kaiser et al., 2000 ), who reported that IL-6 is usually indicative of the initiation of an acute-phase response and is produced following infection with $S$. Typhimurium in vitro model of avian cell culture.

\section{Effect of Salmonella infection on hematological parameters \\ Infection with Salmonella spp. in ducks significantly $(\mathrm{P}<0.05)$ decreased RBCs, Hb, PCV, Phagocytic activity $\%$ and Phagocytic index while, significantly $(\mathrm{P}<0.05)$}


increased WBCs, neutrophil, and lymphocyte compared with noninfected (Table 10). Infection with Salmonella spp. in ducks significantly $(\mathrm{P}<0.05)$ decreased serum albumin while, significantly $(\mathrm{P}<0.05)$ increased blood serum globulin, uric acid, creatinine, AST and ALT concentrations compared with non-infected (Table 10).

Changes that happened in the blood picture and biochemical values are a mirror of the changes that occurred in the tissues and organs as a result of bacterial infection. These findings agreed with those reported by, (Assoku et al., 1970) and (Kokosharov, 2006), who discussed that there were decreased in RBCs, $\mathrm{Hb}$ and PCV in poultry infected with $S$. Gallinarium. Increased values of WBCs, neutrophil, and lymphocyte agreed with (Morgulis, 2002), who recorded that Leukocytosis is usually due to heterophilia, and common causes are general infections due to septicemias caused by infectious agents, such as Salmonella and disagreed with Allan and Duffus (1971), found no changes in lymphocyte counts during fowl typhoid and Assoku et al. (1970), worked at $S$. Gallinarium in birds, and noticed that the count of lymphocyte was lower than the normal values. There were no important changes in the percentage of eosinophil, monocyte, and basophil, these results were coordinated with previous results (Cardoso et al., 2003 and Freitas Neto et al., 2007). Decreased level in Phagocytic activity $\%$ and Phagocytic index agreed with (Belih et al., 2016).

There was a decrease in albumin, AST, ALT and increased globulin (Table 11), which agreed with (Freitas Neto et al., 2007), who reported that serum albumin was lower while ALT and AST were higher in S. Gallinarium infection. This may be due to the inability of protein synthesized by the liver which reflects lesion intensity, visibly proven by hepatomegaly and loss of protein by the affected kidney. Therefore, the damage in the glomerular filtration barrier, inflammation of the renal parenchyma or epithelial damage of the tubules leads to the presence of plasma proteins in the urine (Relford and Lees, 1996).

In the present work, Salmonella infection significantly increased serum creatinine and uric acid levels in Salmonella infected group, that agreed with Hegazy et al. (2014).

\section{CONCLUSION}

Results of antibiotic sensitivity demonstrated that amikacin could be used for ducks against Salmonella infection. Molecular analysis showed that virulence genes of invA, hilA and fimA were found in all Salmonella strains isolated from ducklings. The invA gene is present only in
Salmonella species and therefore is used as a golden marker in the genetic diagnosis of Salmonella species. It is concluded that Salmonella had immunosuppressive effects and destructive effects on the liver and kidney.

\section{REFERENCES}

Abd El-Tawab AA, Nabih AM, Agag MA, Ali A and Marwah H (2017). Molecular studies of virulence genes of Salmonella Typhimurium causing clinical mastitis in dairy cattle. Benha Veterinary Medical Journal, 33(2): 27-37. Available at: http://www.bvmj.bu.edu.eg

Abd El-Tawab A, El-Hofy FI, Ammar AM, Nasef SA and Nabil NM (2015). Molecular studies on antimicrobial resistance genes in Salmonella isolated from poultry flocks in Egypt. Benha Veterinary Medical Journal, 28(2): 176-187. Available at: http://www.bvmj.bu.edu.eg

Abd-El-Rahman, Mahmoud A and Moussa HMM (2000). Bacteriological and histopathological studies on Salmonella isolates from ducks in North Sinai. Egyptian Journal of Agricultural Research, 78(1):15-24. Available at: https://www.cabdirect.org/cabdirect/abstract/20013148120

Adzitey F, Rusul G and Huda N (2012). Prevalence and antibiotic resistance of Salmonella serovars in ducks, duck rearing and processing environments in Penang, Malaysia. Food Research International,45(2):947-952. Available at: https://www.sciencedirect.com/science/article/pii/S0963996911001 530

Alcaine SD, Soyer Y, Warnick LD, Su WL, Sukhnan S , Richards J, Fortes ED, McDonough P, Root T P, Dumas NB, Gro hn Y and Wiedmann M (2006). Multilocus sequence typing supports the hypothesis that cow- and human-associated Salmonella isolates represent distinct and overlapping populations. Applied and Environmental Microbiology, 72: 7575-7585. Available at: https://aem.asm.org/content/aem/72/12/7575.full.pdf

Allan D and Duffus WPH (1971). The immunopathology in fowls (Gallus domesticus) of acute and subacute Salmonella Gallinarum infection. Research in Veterinary Science, 12(2): 140-151. DOI: https://doi.org/10.1016/S0034-5288(18)34207-3

American Association of Avian Pathologists (AAAP) (1989). A Laboratory manual for the isolation and identification of avian pathogens. Third Edition. Kendall/Hunt. USA.

Arliss JO and Entvistle WM (1981). Enzymatic determination of uric acid. Clinical Chemistry Acta, 118:301-309

Assoku RKG, Penhale WJ and Buxton A (1970). Haematological changes in acute experimental Salmonella Gallinarum infection in chickens. Journal of Comparative Pathology, 80(3): 473-485. DOI: https://doi.org/10.1016/0021-9975(70)90080-0

Barrow PA, Huggins MB, Lovell MA and Simpson JM (1987). Observations on the pathogenesis of experimental Salmonella Typhimurium infection in chickens. Veterinary Science, 42:194199. DOI: https://doi.org/10.1016/S0034-5288(18)30685-4

Barrow PA, Lovell MA, Murphy CK and Page K (1999). Salmonella infection in a commercial line of ducks; experimental studies on virulence, intestinal colonization and immune protection. Eidemiology and Infection, 123(1):121-32. DOI: https://doi.org/10.1017/S0950268899002605

Batikh M. (2018). Epidemiological studies on transmission of avian pathogens from fish farms to water fowls in Kafr El-Sheikh governorate. Doctor of Philosophy Thesis, Poultry disease department, Faculty of Veterinary Medicine, Cairo University, Egypt. 
Belih S, EL-Hadad S, Amen G and Basiony MR (2016). Influence of sodium butyrate on Salmonella infection in broiler chicks. Benha Veterinary Medical Journal, 31(2): 21-32. Available at: http://www.bvmj.bu.edu.eg

Bjerrum CL, Engberg RM and Pedersen K (2003). Infection models for Salmonella Typhimurium DT110 in day-old and 14-day-old broiler chickens kept in isolators. Avian Diseases, 47(4): 1474-1480. DOI: https://doi.org/10.1637/7051

Britton CJ (1963). Disorders of the Blood, 9th ed. I. A. Churchill, Ld. London. The United Kingdom.

Cardoso A LSP, Tessari EN and Castro AG (2003). Estudo hematológico em aves inoculadas com Salmonella Gallinarum. Arquivos do Instituto Biológico, 70(1): 35-42. Available at: http://www.biologico.sp.gov.br/uploads/docs/arq/V70_1/cardoso.p df

Chiu LH, Chiu CH, Horn YM, Chiou CS, Lee CY, Yeh CM, Yu CY, Wu CP, Chang CC and Chu C (2010). Characterization of 13 multi-drug resistant Salmonella serovars from different broiler chickens associated with those of human isolates. BMC Microbiology, 10:86. Available at: https://link.springer.com/content/pdf/10.1186/1471-2180-10-86.pdf

CLSI (2018). Performance standards for antimicrobial disk susceptibility tests; approved standard $12^{\text {th }}$ Edition.

Coble DJ, Redmond SB, Hale B and Lamont SJ (2011). Distinct lines of chickens express different splenic cytokine profiles in response to Salmonella Enteritidis challenge. Poultry Science, 90(8): 16591663.

Cohen HJ, Mechanda SM and Lin W (1996). PCR amplification of the fimA gene sequence of Salmonella Typhimurium, a specific method for detection of Salmonella spp. Applied and Environmental Microbiology, 62(12):4303-8. Available at: https://aem.asm.org/content/62/12/4303.short

Dong P, Zhu L, Mao Y, Liang R, Niu L, Zhang Y, Li K and Luo X (2014). Prevalence and profile of Salmonella from samples along the production line in Chinese beef processing plants. Food Control, 38:54-60. https://doi.org/10.1016/j.foodcont.2013.09.066

Doumas BT, Bayso DD, Carter RJ, Peters T and Schaffer R (1981). Determination of total serum protein. Clinical Chemistry, 27: 1642-1643.

Edwards PR, Ewing WH ( 1986). Edwards and Ewing's identification of Enterobacteriaceae (4 ${ }^{\text {th }}$ Edition.), New York, U.S.A: Elseviers Science Publishing Co., Inc.

Elgohary AH, Abu Elnagai AAM, Ibrahim HS, Hedia RH, Dorgham SM and Elgabry EA (2017). Detection of virulence genes of Salmonella in diarrheic ducks by using polymerase chain reaction (PCR). Egyptian Journal of Veterinary Science, 48(1): 11-21. Available at: https://ejvs.journals.ekb.eg/article_3994_d62ce1329fe53bd4c4daee 776968a688.pdf

Freitas Neto OC, Arroyave W, Alessi AC, Fagliari JJ and Berchieri A (2007). Infection of commercial laying hens with Salmonella Gallinarum: clinical, anatomopathological and haematological studies. Brazilian Journal of Poultry Science, 9(2): 133-141. DOI: http://dx.doi.org/10.1590/S1516-635X2007000200010

Gong J, Xu M, Zhu C, Miao J, Liu X, Xu B, Zhang J, Yu Y and Jia X (2013). Antimicrobial resistance, presence of integrons and biofilm formation of Salmonella Pullorum isolates from eastern China (1962-2010). Avian Pathology, 42: 290-294. DOI: https://doi.org/10.1080/03079457.2013.788129

Grimont PA and Weill FX (2007). Antigenic formulae of the Salmonella Serovars, WHO Collaborating Center for Reference and Research on Salmonella, Paris. ( $9^{\text {th }}$ Edition). Available at: http://www.pasteur.fr/sante/clre/cadrecnr/salmoms-index.html
Guran HS, Mann D, Alali WQ (2017). Salmonella prevalence associated with chicken parts with and without skin from retail establishments in Atlanta metropolitan area, Georgia. Food Control, $\quad 73: 462-7 . \quad$ DOI: https://doi.org/10.1016/j.foodcont.2016.08.038

Hegazy AMa, Barakat Mb , Sabreen E Fadlb and El-Keredy MS Abeer (2014). Effect of Pedicoccus acidilactici on immunity, production and lipid profile in broilers. Alexandria Journal of Veterinary Sciences, 41: 35- 46. DOI: https://doi.org/10.5455/ajvs.158314

Henry RJ, Canmon DC and Winkelman JW (1974). Determination of calcium by atomic absorption spectrophotometry. In: Henry RJ, Cannon DC, Winkelman JW (eds) Clinical chemistry: principles and techniques, $2^{\text {nd }}$ Ed. Harper and Row, Maryland, p 657.

Here L, Wagenaar JA; Vanknapen F and Urlings BAP (2003). Passage of Salmonella through the crop and gizzard of broiler chickens fed with fermented liquid feed. Avian Pathology, 32: 173-181. DOI: https://doi.org/10.1080/0307945021000071597

Hoszowski A and Wasyl D (2005). Salmonella prevalence and resistance to antibiotics in Poland. Medycyna Weterynaryjna, 61(6):660-663.

Jain NC (1986). Schaulm Veterinary Haematology $4^{\text {th }}$ Edition, Lea and Febiger. Philadelphia.

Kaiser P, Rothwell L, Galyov EE ,Barrow PA, Burnside J and Wigley $P$ (2000). Differential cytokine expression in avian cells in response to invasion by Salmonella Typhimurium, Salmonella Enteritidis and Salmonella Gallinarum. Microbiology, 12:32173226. DOI: https://doi.org/10.1099/00221287-146-12-3217

Kaneko JJ (1989). Clinical biochemistry of domestic animals. $4^{\text {th }}$ Edition. Academic Press lnc. New York .146-159:612-647.

Kleven SH and Yoder HW (1998). Mycoplasmosis. In: HG Purchase, LH Arp, CH Domermuth and JE Pearson (Eds). A Laboratory manual for the isolation and identification of avian pathogens.

Kokosharov $\mathrm{T}$ (2006).Changes in the protein profile in birds with experimental acute fowl typhoid. Bulgarian Journal of Veterinary Medicine,9(3): 189-192. Available at: https://pdfs.semanticscholar.org/f4bf/8e577513bb09afc12adb63c8e 82ae443fe0f.pdf

Lucas AM and Jamroz C (1961). Atlas of avian hematology. US Department of Agriculture. Washington, DC, Agriculture Monograph 25.4th Edition, American Association of Avian Pathologists, Kenett Square, pp. 74-88.

Malorny B, Hoorfar J, Bunge C and Helmuth R ( 2003). Multicenter validation of the analytic accuracy of Salmonella PCR: toward an international standard. Applied Environmental Microbiology, 69: 290-296. Available at https://aem.asm.org/content/aem/69/1/290.full.pdf

Michael P and Malcolm W ( 2006). Measurement of serum creatininecurrent status and future goals. The Clinical Biochemist Reviews,27(4): 173-184. Available at: https://www.ncbi.nlm.nih.gov/pmc/articles/PMC1784008/pdf/cbr2 7_4p173.pdf

Mohamed T shaaban, Hegazy AM and Sami I Menisy (2015). Microbiological and molecular studies on Salmonella spp. isolated from broilers in Kafr El.sheikh governorate, Egypt. Journal of Bioscience and Applied Research, 1(2):59-67.

Morgulis M (2002). Imunologia aplicada. In: Macari M, Furlan RL, Gonzalez E editors. Fisiologia aviária aplicada a frangos de corte. Jaboticabal: FUNEP/ UNESP, pp.375-429.

Natt MP and Herrick CA (1952). A new blood diluent for counting the erythrocytes and leucocytes of the chicken. Poultry Science, 31:735-738. DOI: https://doi.org/10.3382/ps.0310735

Oliveira SD, Rodenbusch CR, Ce MC, Rocha SLS and Canal CW (2003). Evaluation of selective and non- selective enrichment PCR procedures for Salmonella detection. Lett. Applied Microbiology, 
Abou Zeid et al., 2020

36: 217-221. DOI: https://doi.org/10.1046/j.1472765X.2003.01294.X

Osman KM, Moussa IMI, Yousef AMM, Aly MM, Radwan MI and Alwathnani HA (2010). Pathogenicity of some avian Salmonella serovars in two different animal models: SPF chickens and BALB/c mice. Environment and We An International Journal of Science and Technology,5: 65-78.

Reitman S and Frankel S (1957). A colorimetric method for the determination of serum glutamic oxaloaceitic and glutamic pyruvic transaminases. American Journal of Clinical Pathology, 28:56-63.

Relford RL and Lees GE (1996). Nephrotic syndrome in dogs: diagnosis and treatment. Journal of Compendium on Continuing Education Practicing Veterinarian, 18:279-292.

Ribeiro SAM, Berchieri Jr A, Orsi MA, Mendonça AO and Ferrati AR (2005). Experimental infection by Salmonella enterica subsp enterica serovar Kottbus in day-old broiler chickens. Brazilian Journal of Poultry Science, 7(2): 107-112. DOI: http://dx.doi.org/10.1590/S1516-635X2005000200007

Richardson MD and Smith H (1982). Differentiation of extracellular from ingested Candida albicans blastospores in phagocytosis tests by staining with fluorescein-labelled concanavalin A. Journal of Immunological Methods, 52(2):241-244. DOI: https://doi.org/10.1016/0022-1759(82)90050-3

Sabbagh SC, Forest CG, Lepage C, Leclerc JM and Daigle F (2010). Uncovering distinctive features in the genomes of Salmonella enterica serovars Typhimurium and Typhi. FEMS. Microbiological Letters,305(1):1-13. DOI: https://doi.org/10.1111/j.15746968.2010.01904.x

Schwarz S, Silley P, Simjee S, Woodford N, van Duijkeren E, Johnson AP and Gaastra W (2010). Assessing the antimicrobial susceptibility of bacteria obtained from animals. Journal of Antimicrobial Chemotherapy, 65(4): 601-604. DOI: https://doi.org/10.1093/jac/dkq037
Shamoon GN, Ali TS and Al-Atar MY (1998). Isolation of Salmonella from local ducks. Iraqi Journal of Veterinary Sciences, 11(2):7568.

Smith AL and Beal R ( 2008). The avian enteric immune system in health and disease. In: Davison F, Kaspers B, Schat KA, eds. Avian immunology, London: Academic Press: 243-71.

Stevens MP, Humphrey TJ, and Maskell DJ (2009). Molecular insights into farm animal and zoonotic Salmonella infections. Philosophical Transaction of the Royal Society B. London,364: 2709-2723. DOI https://doi.org/10.1098/rstb.2009.0094

Suzuki K, Okada H, Itoh T, Tada T, Mase M, Nakamura K, Kubo M and Tsukamoto K (2009). Association of increased pathogenicity of Asian H5N1 highly pathogenic avian influenza viruses in chickens with highly efficient viral replication accompanied by early destruction of innate immune responses. Journal of Virology, 83 (15): $\quad 7475-7486 . \quad$ Available at: https://jvi.asm.org/content/jvi/83/15/7475.full.pdf

Thung TY, Radu S, Mahyudin NA, Rukayadi Y, Zakaria Z, Mazlan N, Tan BH, Lee E, Yeoh SL, Chin YZ, Tan CW, Kuan CH, Basri DF and Wan Mohamed Radzi Che WJ (2018).Prevalence, virulence genes and antimicrobial resistance profiles of Salmonella serovars from retail beef in Selangor, Malaysia. Frontiers in Microbiology, 8: 2697. DOI: https://doi.org/10.3389/fmicb.2017.02697

Yang X, Brisbin J,Yu H,Wang Q,Yin F,Zhang Y, Sabour P, Sharif S and Gong J (2014).Selected lactic acid-producing bacterial isolates with the capacity to reduce Salmonella translocation and virulence gene expression in chickens.PLOS ONE, 9(4): e93022. .Available https://www.ncbi.nlm.nih.gov/pmc/articles/PMC3984083/

Yuan JS, Reed A, Chen F and Stewart CN (2006). Statistical analysis of real-time PCR data. BMC Bioinformatics, 7(1):85. Available at: https://link.springer.com/content/pdf/10.1186/1471-2105-7-85.pdf 